\title{
IAMJ
}

INTERNATIONAL

AYURVEDIC

MEDICAL JOURNAL

ISSN: 23205091

Impact Factor: 6.719

\section{AYURVEDIC MANAGEMENT OF CERVICAL INTRAEPITHELIAL NEOPLASM GRADE - I: A CASE REPORT}

\author{
Neetha Surendran ${ }^{1}$, Anita K Patel $^{2}$ \\ ${ }^{1}$ Professor, Department of Prasuti Tantra And Striroga, VPSV Ayurveda College, Kottakkal, Kerala, India \\ ${ }^{2}$ Associate Professor, SCSVMV University, Kanchipuram, Tamilnadu, India
}

Corresponding Author: neethasdr@gmail.com

https://doi.org/10.46607/iamj14p5012020

(Published online: November 2020)

Open Access

(C) International Ayurvedic Medical Journal, India 2020

Article Received: 23/11/2020 - Peer Reviewed: 26/11/2020 - Accepted for Publication: 26/11/2020

Check for updates

\begin{abstract}
Cervical intraepithelial neoplasm (CIN) is a pre-cancerous condition which is strongly associated with the infection of human papilloma virus. It is nowadays common among women in the age of 25-35 years. It is done to know whether the Ayurvedic management of CIN- I is possible using the line of treatment of Sannipathika Vrana. Initially vrana Sodhana was done by using Yoni Kshalana, Yoni Pratisarana and Yoni Kalkadharana. Then Vrana Ropana Chikitsa was adopted. To prevent the remission of the disease and to boost the immunity Rasayana therapy was also done. The signs and symptoms got relieved completely and the Pap test showed normal smear. CIN-I can be cured using the Chikitsa of Sannipathika Vrana.
\end{abstract}

Keywords: CIN grade I, human papilloma virus, Garbhasayamukhagatha Vrana, Sannipathika Vrana, Rasagandhi Mezhuku

\section{INTRODUCTION}

Cervical intraepithelial neoplasm (CIN) is a precancerous condition in which cells on the surface of cervix undergo abnormal growth ${ }^{[1]}$. In India, cervical cancer contributes to approximately $6-29 \%$ of all cancers in women. It is the second most common cancer among women. CIN can affect at any age, 
however prevalence is greater among the age groups of 25-35 years. ${ }^{[2]}$

CIN is strongly associated with sexually transmitted human papillomavirus (HPV) infection of cervix. In most cases the immune system eliminates HPV and clears the infection. But in chronic infection especially with high risk HPV 16 or HPV 18 types, it may inactivate tumor suppressor genes (P53 gene and RB gene) and eventually leading to cancer. ${ }^{[1]}$

The main risk factors for CIN are long term use of contraceptive, multiple sexual partners, immuno deficiency disorders, smoking etc ${ }^{[1]}$

There are no specific symptoms for CIN alone. Generally, women suffering from CIN present with, ${ }^{[1]}$

- vaginal bleeding after intercourse, between periods or after menopause.

- watery, blood stained vaginal discharge that may be heavy with foul odour.

- unexplained persistent pelvic pain or back pain

- dyspareunia

Routine Papanicolaou test (Pap test) can detect precancerous conditions of the cervix. Based on pap test CIN can be classified in 3 grades, CIN 1(GRADE I), CIN 2(GRADE II) and CIN (GRADE III). ${ }^{[1]}$

Conventional management for higher grade CIN includes removal or destruction of the abnormal cervical cells by cryocautery, electrocautery, laser cautery etc. ${ }^{[3]}$

CIN may be correlated with Sannipathika Vrana at Garbhasaya Mukha with symptoms like Ruja, Dhoomayana, Daha, Paka, Raga etc at vulval area. ${ }^{[4]}$ The general line of treatment includes Sodhana ${ }^{[5]}$ and Ropana $^{[6]}$. Sodhana Karma was done to convert this Dushta Vrana to Sudha Vrana. Along with that
Sarvadehika Amapachana drugs were also given. For these purposes Aushadha with Amahara, Kledahara, Lekhana, Vranaropana properties and Tiktharasa Pradhana were used. After the inflammation subsided Pratisarana Kshara ${ }^{[7]}$ was applied to remove the unhealthy tissues present in the Vrana and to promote the healing process.

Along with above mentioned Sthanika Chikitsa, Sarvadehika Chikitsa was also done using Rasagandhi Mezhuku capsule ${ }^{[8]}$, Guggulu Tikthakam Kashaya ${ }^{[9]}$, Guggulu Panchapala Churna ${ }^{[10]}$, Guggulu Tikthaka Ghritha ${ }^{[9]}$ etc.

\section{Methods - Case Report}

A 32 years old woman came to the Prasoothi OPD of VPSV Ayurveda College Hospital, Kottakkal with complaints of excessive yellowish discharge per vagina, lower abdominal pain and itching in the vulval area since 6 months along with occasional post coital spotting on the same day or on the very next day of coitus and recurrent urinary tract infection (UTI) since 2 months. She had a regular menstrual cycle of $7 / 28$ duration without any associated complaints. But since 2 months she was having irregular menstrual cycle with intermittent spotting. She got married at the age of 18 and had 2 term deliveries at the age of 19 and 22. She remarried at the age of 28 and went through one abortion and a term delivery $\left(\mathrm{G}_{4} \mathrm{P}_{3} \mathrm{~A}_{1} \mathrm{~L}_{3}\right)$.

\section{Personal History}

Diet - vegetables and non-vegetables

Appetite - Poor

Bowel habit - 1-2 per day, hard stools

Micturition - 4-5 per day, recurrent UTI

Sleep -Disturbed due to itching at vulval area

Addiction - Nil

Table 1: Dashavidha Pareeksha

\begin{tabular}{|l|l|l|l|}
\hline Dasavidha Pareeksha & Details & Dasavidha Pareeksha & Details \\
\hline Dushya & Mamsa, Medas, Raktha & Anala & Avara \\
\hline Desa & $\begin{array}{l}\text { Deha- Garbhasaya mukha } \\
\text { Bhumi -Jangalasadharana }\end{array}$ & Prakruthi & Vatha-Pitha \\
\hline Bala & Avara & Vaya & Youvana \\
\hline Kala & Varsha & Satwa & Madhyama \\
\hline Anala & Avara & Satmya & Madhyama \\
\hline Pakruthi & Vathapitha & Ahara & $\begin{array}{l}\text { Abhyavaharana Sakthi-Avara } \\
\text { Jarana Sakthi- Avara }\end{array}$ \\
\hline
\end{tabular}


Clinical examination was done. On inspection of external genitalia, yellowish discharge and slight inflammation of vulva was seen which indicated pruritis vulva. Per speculum examination revealed hypertrophied, highly vascular, highly eroded cervix which bled on wiping and profuse yellowish discharge in the vagina. On per vaginal examination, anteverted uterus, first degree uterine descent and tenderness at left lateral fornix were noticed. The patient was advised to do Pap test to confirm the histopathological condition of the cervix and to exclude cervical malignancy. Inorder to rule out other diseases, blood, urine and sonological investigations were advised.

Table 2: Investigations

\begin{tabular}{|l|}
\hline Investigations \\
\hline Blood Routine \\
\hline Urine Routine \\
\hline Blood sugar \\
\hline USG- Abdomen and pelvis \\
\hline
\end{tabular}

Results

Haemoglobin - 10g/dL

ESR - $60 \mathrm{~mm} / \mathrm{hr}$

$\mathrm{RBC}$ - occasional

Pus - 10-12 hpf

Bacteria - present

RBS - $110 \mathrm{mg} / \mathrm{dL}$

Bulky uterus with $10 \times 6 \times 3 \mathrm{~cm}$ measurement. No other sonologically detected abnormalities.

- Patolakaturohinyadi Kashaya ${ }^{[11]}-15 \mathrm{ml}$ Kashaya with $45 \mathrm{ml}$ luke warm water, twice daily, on empty stomach

- Vilwadi Gulika ${ }^{[12]_{-}}$with Surasa Swarasa, 1-0-1, before food

- Guggulupanchapala Churna - 5g, with honey, twice dailyy, after food

- Avipathy Churna ${ }^{[13]}-5 \mathrm{~g}$, with hot water, bed time

level.

Sarvadehika Aushadhas (Internal Medicines- for 2 weeks)

\section{Sthaanika Aushadha (Localised Medicines)}

\begin{tabular}{|c|c|c|}
\hline Time and Duration & Procedure with Medicines & Time and Duration \\
\hline \multirow{4}{*}{$\begin{array}{l}1-14 \text { days } \\
\text { Morning hours }\end{array}$} & Vaginal douche (Yonikshalana) - Guluchyadi Kashaya ${ }^{[14]}$ & \multirow{3}{*}{$\begin{array}{c}1-7 \text { days } \\
\text { Evening hours }\end{array}$} \\
\hline & Pratisarana - Guggulupanchapala Churna (5 minutes) & \\
\hline & $\begin{array}{l}\text { Vaginal douche - Kashaya made with Harida, Shireesha } \\
\text { Twak and Nimba Pathra }\end{array}$ & \\
\hline & $\begin{array}{l}\text { Kalka Dharana - Guggulupanchapala Churna in } \\
\text { Guluchyadi Kashaya }\end{array}$ & \\
\hline
\end{tabular}

After the next menstrual cycle, Kshara Karma was done using Apamarga Kshara on the eroded area of the cervix followed by minimal yoni Kshalana with Guluchyadi Kashaya. She was then discharged and was advised to take the internal medicines and follow the Pathya-Apathya.

\section{Discharge Medicines (8 weeks)}

- Guggulu Tikthaka Kashaya - 15 ml Kashaya with $45 \mathrm{ml}$ lukewarm water, twice daily, on empty stomach

- Rasagandhi Mezhuku capsule - with milk, 1-0-1, after food 
- Avipathy Churna - 10g, for Virechana, weekly once, bed time

\section{Pathya-Apathya}

- Complete rest for 2 weeks

- Rest with minimal activity for further 6 weeks

- Intake of plenty of water

- Avoid intercourse during the whole course of treatment

Review was done. Assessment of symptoms were done on $2^{\text {nd }}, 4^{\text {th }}, 6^{\text {th }}$ and $8^{\text {th }}$ week and per-vaginal examination was done on $8^{\text {th }}$ week of Ksharakarma to note the condition of the cervix. It was noticed that the erosion was replaced with healthy epithelium.

Following these, Guggulu Tikthaka Ghritha - 1 tsp, twice daily, empty stomach, given internally for following 2 months.

The patient was advised to repeat Pap test after the $4^{\text {th }}$ month of Ksharakarma to note any changes, and it showed normal smear with no evidence of CIN-I and HPV infection.
Then Rasayana therapy was adopted for next 3 months using ksheerakashaya of Vidari, Aswagandha and Shathavari, at bed time.

After 6 months she was again advised to repeat Pap test which revealed normal cervical epithelium.

\section{DISCUSSION}

According to Sushrutha Samhitha (first chapter) Vran Gathra Vichurnane, Vranayathi Ithi Vranaha

The term vrana indicates a discontinuity in the healthy tissue of body. There are 14 types of Vrana based on dosha predominance. Among them, the condition CINI may be correlated as the Sannipathika Vrana.

In CIN -I there may be a vitiation of the tridosha with sthanasamsraya at garbhasayamukha due to the indulgence of ahitha ahara and vihara and thus resulting in an altered functioning of Srotas.

Initially the amavastha has to be get rid of by both Sarvadehika and Sthanika management. For that following medicines were advised for 14 days.

\begin{tabular}{|l|l|}
\hline Medicines & Properties \\
\hline & Balances Pitha-Kapha Dosha \\
\hline Patolakaturohinyadi kashaya & Reduces Daha \\
\hline & Promotes digestion \\
\hline Vilwadi Gulika with Surasa Swarasa & Rejuvenates epithelium \\
\hline Guggulupanchapala Churna & Amahara \\
& Vishahara \\
\hline Avipathy Churna (Samana dose) & Krimihara \\
\hline
\end{tabular}

In the management of Vrana, more importance was given to Sthanika Chikitsa than the Sarvadehika Chikitsa. According to Acharya Susrutha, in vrana cikitsa, intially Sodhana Karma should be done followed by ropana line of management. Proper Sodhana Karma makes a vrana sudha and it aids the ropana karma. It generally seemed like wound with healthy granulation tissues grows faster than the wounds with unhealthy tissues. In the first 14 days of Sthanika Chikitsa (localised treatment) were done for the Sodhana of Vrana by means of vaginal douche, Pratisarana and Kalkadharana.

\begin{tabular}{|l|l|}
\hline Medicines & Properties \\
\hline Guluchyadi Kashaya & $\begin{array}{l}\text { Pitha-Kaphahara } \\
\text { Amahara }\end{array}$ \\
\hline Nimba Patra + Shireesha Twak+ Haridra & Pitha-Kaphahara \\
\hline
\end{tabular}




\begin{tabular}{|l|l|}
\hline & Krimigna \\
& Vranahara \\
\hline Guggulupanchapala Churna & Kapha-Vathahara \\
& Lekhana \\
& Kledana \\
& Pakahara \\
\hline
\end{tabular}

Per speculum examination was done on the $14^{\text {th }}$ day of treatment, which showed reduction in hypertrophy, vascularity and inflammation of the cervix. But the erosion remained as the same.

After the $14^{\text {th }}$ day of treatment Vrana attained the features of Sudhavrana and became yogya for Ropana Karma. Ksharakarma using Apamarga Kshara was planned after the commencement next menstrual cycle. Kshara is an Anu-Sasthra which has the following properties Tridoshagna, Sodhana, Ropana and Lekhana. Apamarga Kshara was applied at the site of erosion for 3 minutes followed by minimal vaginal douche with Guluchyadi Kashaya as pitha Samana.

The patient was then discharged and advised to follow pathya-apathyas strictly. For the next 8 weeks he was advised to take Guggulutikthaka Kashaya and Rasagandhi Mezhuku capsule and along with these patient was directed to do virechana,once in a week with Avipathy Churna. In effect the combination helped to reduce the Dushitha Medas, Kleda and Mamsa. Rasagandhi Mezhuku is a Herbomineral Sidha preparation from the reference of Pulipani Vaidyam 500 by Pulipani Sidhar. Arbudhagna property of Rasagandhi Mezhuku capsule was used to check the unconditional growth of cancerous epithelial cells.

On the $8^{\text {th }}$ week, per speculum examination was again done and it is observed that cervical erosion was healed and replaced with normal epithelium.

Then for the next 2 months, Guggulutikthaka Ghritha given internally as Samana Snehapana to purify the blood, clear the deep seated toxins from the metaplastic epithelium and to accelerate the removal remnants if present.

After the $4^{\text {th }}$ month of Ksharakarma Pap test was repeated and it showed normal smear with no evidence of CIN-I or HPV infection.
To improve the immunity and to maintain the healthy tissues in cervix Rasayana therapy was done, for that intake of Ksheerakashaya made using vidari, Aswagandha and Shathavari was prescribed for 3 months.

Pap test repeated after 6 months showed negative result for genital malignancy.

\section{RESULT}

Assessment of the signs and symptoms in the present case was done after the $4^{\text {th }}$ month of treatment and there was no evidence of the previous complaints. From this it can be inferred that complete cure of CIN-I is possible via this Ayurvedic protocol.

\section{CONCLUSION}

From this study we can infer that Sannipathika Vrana Chikitsa is effective in CIN -I. Here both Sarvadehika and Sthanika Chikitsa were used and it include Kshara karma, Rasagandhi Mezhuku etc which promted the cleaning and healing of vrana. In the follow up period Rasayana therapy improved the immunity, thereby remission can be avoided.

\section{REFERENCES}

1. Mello V, Sundstrom RK. Cervical Intraepithelial Neoplasia (CIN). StatPearls [Internet]. 2020 Aug 12.

2. Bobdey S, Sathwara J, Jain A, Balasubramaniam G. Burden of cervical cancer and role of screening in India. Indian journal of medical and Paediatric Oncology: official journal of Indian Society of Medical \& Paediatric Oncology. 2016 Oct;37(4):278.

3. Martin-Hirsch PP, Paraskevaidis E, Bryant A, Dickinson HO, Keep SL. Surgery for cervical intraepithelial neoplasia. Cochrane database of systematic reviews. 2010(6).

4. Murthy S.K.R. Suśruta Samitha (with English translation): Chaukhamba Orientalia publications, Varanasi;2012; vol II: Chikitsa Sthana, chapterr.1/6. p 4 
5. Murthy S.K.R. Suśruta Samhitha (with English translation): Chaukhamba Orientalia publications, Varanasi;2012; vol II: Chikitsa Sthana, chapter.1/53. p 15

6. Murthy S.K.R. Suśruta Samihitha (with English translation): Chaukhamba Orientalia publications, Varanasi;2012; vol II: Chikitsa Sthana, chapter.1/63. p 17

7. Murthy S.K.R. Suśruta Samhitha (with English translation): Chaukhamba Orientalia publications, Varanasi;2012; vol I: Suthra Sthana, chapter.11/7. p 64

8. Dev G.A. et al. A Review of Rasagandhi Mezhuku For Arbudas Related To Shalakya Tantr. IAMJ: 3 (1); January 2015

9. Murthy S.K.R. Ashtanga Hridaya (with English translation): Chaukhamba Orientalia publications, Varanasi;2012; vol II: Chikitsa Sthana, chapter.21/58. p 508

10. Murthy S.K.R. Ashtanga Hridaya (with English translation): Chaukhamba Orientalia publications, Varanasi;2012; vol II: Uthara Sthana, chapter.28/40. p 40

11. Murthy S.K.R. Ashtanga Hridaya (with English translation): Chaukhamba Orientalia publications, Varanasi;1999; vol I: Suthra Sthana, chapter.15/15. p. 202

12. Murthy S.K.R. Ashtanga Hridaya (with English translation): Chaukhamba Orientalia publications, Varanasi;2012; vol II: Uthara Sthana, chapter.36/84. p 357

13. Murthy S.K.R. Ashtanga Hridaya (with English translation): Chaukhamba Orientalia publications, Varanasi;2012; vol II: Kalpa Sthana, chapter.2/21. p 542

14. Murthy S.K.R. Ashtanga Hridaya (with English translation): Chaukhamba Orientalia publications, Varanasi;1999; vol I: Suthra Sthana, chapter.15/16. p. 202

\section{Source of Support: Nil \\ Conflict of Interest: None Declared \\ How to cite this URL: Neetha Surendran \& Anita K Patel: Ayurvedic Management of Cervical Intraepithelial Neoplasm Grade-I: A Case Report. International Ayurvedic Medical Journal \{online\} 2020 \{cited November, 2020\} Available from: http://www.iamj.in/posts/images/upload/2632_2637.pdf}

